\title{
QUALITY BY DESIGN DENGAN METODE TAGUCHI, KONSEP DAN PERKEMBANGANNYA
}

\author{
Moh. Hartono ${ }^{1}$
}

\begin{abstract}
Industrial manufacture developing is dramatically progressing now followed by dinamic environmental changes. To give this customer voices, industrial manufacture have to always increase the quality. In the other hand there have been changes of quality paradigma, that's about problem solving and inspection, become quality engineering in process and product with Robust design approaching. This concept idea is getting quality process and optimum product with noticing noise factors, so that the loss of customers can be minimized. The Robust design is based by the needs of design in process and product have a strenght to an uncontrolled noise factors.
\end{abstract}

\section{Keywords : Robust Design, Signal to Noise Ratio, Noise factors}

\section{PENDAHULUAN}

Perkembangan industri yang sangat pesat dan dinamis dewasa ini khususnya industri manufaktur telah menghadapi kompetisi yang ketat. Untuk menghadapi kompetisi tersebut, perusahaan harus selalu meningkatkan kualitas proses dan produk sesuai dengan tuntutan konsumen. Banyak metode telah diterapkan untuk meningkatkan kualitas proses dan produk, antara lain menggunakan metode rekayasa kualitas dengan desain kokoh (quality by robust design) dalam proses dan produk (Bellavendram, 1995).

Rekayasa kualitas dengan robust design diperkenalkan pada ahli rekayasa kualitas di Amerika Serikat oleh Genichi Taguchi pada awal tahun 1980-an. Pada perkembangan berikutnya, metode ini banyak diterapkan pada industri manufaktur di Jepang, Amerika Serikat,
Eropa dan negara industri baru seperti Korea dan Taiwan. Dengan semakin terkenalnya metode robust design ini, telah terjadi pergeseran paradigma kualitas yaitu dari inspeksi kerusakan dan pemecahan masalah menuju rekayasa kualitas dengan desain dalam proses dan produk (Tsai, 1996).

Luasnya penerapan metode robust design ini, dilandasi oleh kekuatan konsepnya dalam hal pereduksian jumlah kombinasi suatu desain eksperimen sehingga desain yang dihasilkan mampu mengakomodasi eksperimen dengan banyak faktor. Selain itu performansi hasil eksperimen diukur dengan suatu besaran universal yang dapat dipakai untuk membandingkan dua atau lebih variabel yang memiliki dimensi berbeda. Dua hal inilah yang menjadi inti dan kekuatan konsep Taguchi (Kackar, 1985)

Tetapi masih terdapat perdebatan baik kalangan ilmuwan maupun praktisi pada beberapa pendekatan dalam desain parameter 
Taguchi terutama pada 2 hal (Khattree, 1996) yaitu :

1. Penggunaan outer arrays pada noise factors untuk setiap eksperimen yang ada di dalam inner array (yaitu untuk setiap usaha kombinasi perlakuan dalam faktor kontrol),

2. Alasan Taguchi pada penggunaan Signal to Noise Ratios (SNR).

Dalam suatu diskusi panel yang diadakan di Amerika (Nair,1992) yang melibatkan beberapa tokoh peneliti dan praktisi, mendiskusikan masalah tersebut dengan membagi ke dalam beberapa topik antara lain, pentingnya reduksi variasi, penggunaan noise factors, pentingnya interaksi, pemilihan karakteristik kualitas, dan SNR.

\section{TINJAUAN PUSTAKA}

\section{KONSEP ROBUST DESIGN}

\section{Konsep dasar Quality by Design}

Tujuan dari desain rekayasa (engineering design) adalah membuat gambar produk, spesifikasi produk dan kesesuaian informasi yang dibutuhkan untuk membuat produk yang sesuai dengan keinginan konsumen. Metode kualitas dengan desain adalah salah satu dari metodologi desain rekayasa (Bellavendram, 1995).

\section{Pengertian Kualitas Menurut Persepsi}

\section{Konsumen}

$\begin{array}{rrr}\text { Suatu } & \text { produk } & \text { mempunyai } \\ \text { karakteristik } & \text { tertentu } & \text { yang }\end{array}$

menggambarkan performansinya sehubungan dengan persyaratan atau harapan konsumen. Kualitas didefinisikan sebagai keseluruhan gabungan karakteristik produk, mulai dari pemasaran, rekayasa, pembuatan dan pemeliharaan yang membuat produk tersebut memenuhi harapan konsumen. Dengan demikian kualitas yang muncul dari suatu produk merupakan kompromi dari sekelompok karakteristik yang diinginkan konsumen yang berhasil diterjemahkan oleh produsen.

Pada bulan April tahun 1979, sebuah artikel pada sebuah majalah manajemen kualitas di Jepang mendiskusikan preferensi konsumen Amerika terhadap televisi Sony. Menurut konsumen Amerika, televisi Sony buatan Jepang mempunyai kualitas lebih baik dari pada televisi Sony buatan Amerika. Padahal fasilitas pabrik yang digunakan untuk memproduksi di kedua negara tersebut sama. Dari penelitian selanjutnya diketahui ada karakteristik kualitas yang menjadi dasar untuk melakukan screening yaitu voltase rangkaian tahanan. Spesifikasi yang diijinkan untuk voltase rangkaian tahanan adalah $115 \pm$ 20 volt. Di Amerika spesifikasi ini digunakan untuk melakukan screening semua produk. Dengan demikian semua televisi Sony buatan Amerika yang dikirim kepada konsumen dijamin memenuhi spesifikasi diatas. Sedangkan hal diatas tidak dilakukan pada televisi Sony buatan Jepang. Tetapi mengapa preferensi konsumen menyatakan bahwa televisi Sony buatan jepang lebih baik ? Sebenarnya kualitas yang seperti apa yang sesuai dengan preferensi konsumen? 
Studi selanjutnya mengenai proses produksi di Amerika dan Jepang telah menjawab pertanyaan diatas. Jika diperhatikan distribusi dari ketahanan warna, yang diakibatkan oleh rangkaian tahanan, televisi Sony buatan Jepang mempunyai distribusi yang lebih baik.

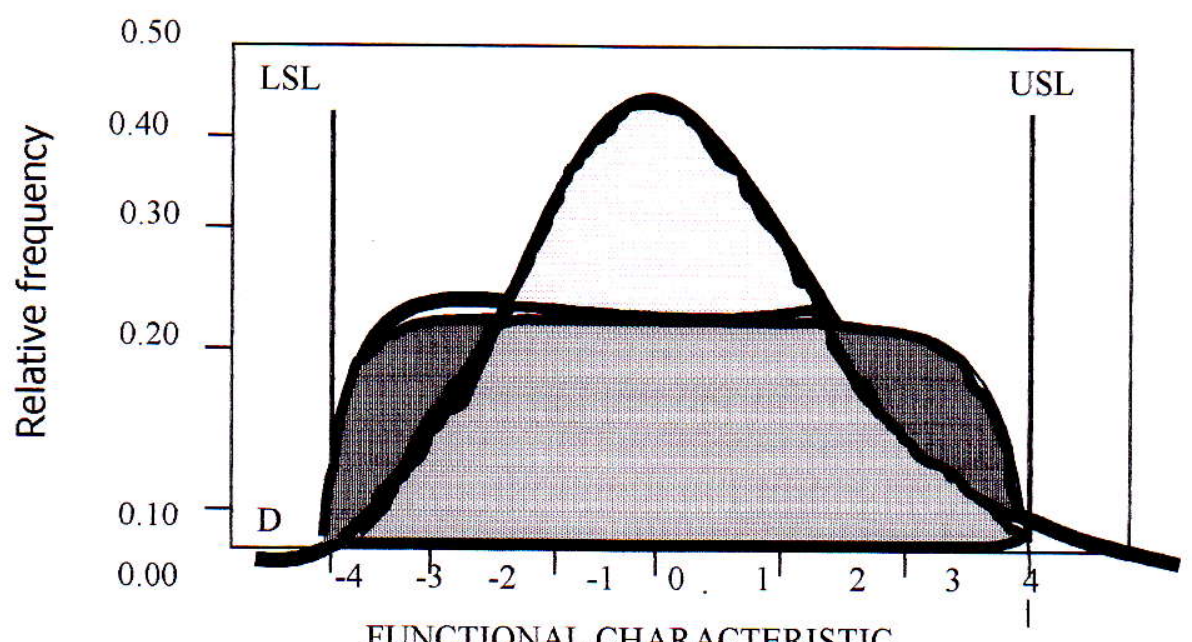

FUNCTIONAL CHARACTERISTIC

Sony Amerika

$\longrightarrow$ Sony Japan

Gambar 1. Distribusi ketahanan warna (Sumber : Belavendran, 1995)

Dari gambar.1 diatas dapat dijelaskan halhal sebagai berikut :

- Daerah A (warna hijau) menunjukkan proporsi yang pada umumnya terjadi pada buatan Amerika dan Jepang.

- Daerah B (warna biru) menunjukkan televisi yang dibuat di Amerika mempunyai performansi lebih jelek dari televisi yang dibuat di Jepang.

- Daerah C (warna kuning) menunjukkan televisi yang dibuat di Jepang mempunyai performansi lebih baik dari televisi yang dibuat di Amerika.

- Daerah D menunjukkan usaha inspeksi $100 \%$ yang dilakukan di Amerika.
Studi ini menunjukkan dengan jelas bahwa televisi Sony yang dibuat di Jepang mempunyai performansi yang lebih unggul. Hal lain yang diperoleh dari studi ini adalah screening $100 \%$ yang dilakukan oleh pabrik Amerika, bukanlah usaha yang tepat untuk meningkatkan performansi kualitas.

Dibandingkan dengan usaha yang dilakukan Jepang yaitu merekayasa proses untuk memfokuskan hasil produksi yang memenuhi target.

\section{Definisi Kualitas Menurut Taguchi}

Mengacu pada kasus televisi Sony diatas, menurut metode konvensional, kualitas yang memenuhi spesifikasi dianggap lebih sempurna oleh pabrik di Amerika. Padahal analisis menunjukkan bahwa dengan merekayasa proses untuk memfokuskan pada target akan dihasilkan kualitas produk yang 
lebih sempurna. Melihat fenomena diatas, Taguchi melihat definisi kualitas dari sisi yang berbeda yaitu dengan melihat hubungan antara kualitas dengan biaya dan kerugian (loss) dalam satuan moneter. Definisi ini tidak hanya memperhatikan segi manufaktur tetapi juga sisi konsumen dan masyarakat. Secara lebih lengkap definisi Taguchi adalah The quality of $a$ product is the minimum loss imparted by the product society from the time the product is shipped. Dengan definisi ini, tujuan dari industri manufaktur adalah membuat produk yang sesuai harapan konsumen selama produksi itu digunakan oleh konsumen. Filosofi Taguchi dalam perbaikan kualitas secara terperinci menekankan pada reduksi variasi. Desain parameter dimaksudkan sebagai pendekatan biaya efektif (cost-effective) pada reduksi variasi dalam proses dan produk (Nair, 1992).

Untuk mengatasi kerugian (loss) karena kualitas yang tidak baik dari suatu produk. Ada dua kemungkinan kerugian yang terjadi setelah produk sampai kepada konsumen yaitu :

- Jika produk tersebut mendapat garansi maka kerugian tersebut ditanggung perusahaan.

- Jika produk tersebut tidak bergaransi konsumen harus mengeluarkan biaya untuk memperbaiki.

Ukuran yang diusulkan Taguchi untuk menghitung kerugian (loss) secara kuantitatif adalah quality loss function. Dengan demikian pendekatan kualitas menurut Taguchi ini merupakan inovasi baru dalam bidang kualitas.

\section{Proses Desain}

Tujuan eksperimen dalam industri manufaktur adalah menemukan cara untuk meminimasi penyimpangan karakteristik kualitas dari target. Hal yang harus dilakukan adalah mengidentifikasi semua faktor yang mempengaruhi karakteristik kualitas serta mencari level faktor yang sesuai sehingga variansi dapat diminimasi. Dalam bahasa teknis, eksperimen dilakukan untuk menentukan material yang terbaik, tekanan yang terbaik, temperatur yang terbaik, formulasi kimia yang cocok, waktu siklus, dimana secara bersama-sama dalam proses produksi menghasilkan karakteristik kualitas seperti dimensi dan daya tahan yang sesuai target.

\section{Perbandingan Pendekatan Eksperimen Klasik dan Taguchi}

Metode desain eksperimen klasik dikembangkan oleh R.A. Fisher di Inggris, metode ini berdasarkan pada pendekatan statistika yang didasarkan pada latin square dan pada awalnya dikembangkan untuk industri pertanian. Metode ini menjadi tidak praktis untuk diterapkan pada industri manufaktur karena adanya asumsi tertentu dan penekanan pada prosedur-prosedur tertentu. Taguchi mengembangkan metode desain eksperimen dengan memanfaatkan sifat desain kokoh (robust design).

Ide dasar dalam desain Taguchi ini adalah untuk mengidentifikasi, melalui penyelidikan interaksi antara parameter kontrol dan noise variable, setting yang tepat 
pada parameter kontrol dengan performansi sistem yang kokoh (robust) terhadap variasi yang tidak dapat dikendalikan (unctrollable variation) dalam z. Dengan kata lain, Taguchi melakukan desain yang kokoh dalam proses dan produk sedemikian sehingga dapat mencegah masuknya faktor yang tidak terkontrol dalam proses produksi dan mencegah masuknya dampak faktor yang tidak terkontrol tersebut pada konsumen. Dari ide dasar ini, maka pendekatan Taguchi tersebut dinamakan desain parameter. Istilah desain ini dimaksudkan sebagai desain dari sistem pada desain eksperimen statistik. Karena tujuannya adalah robust terhadap variasi dalam variabel noise, maka pendekatan ini (desain parameter) disebut juga dengan robust design.

Taguchi memberikan contoh proses pembuatan permen. Kelembutan permen dipengaruhi oleh temperatur lingkungan (noise factors), temperatur yang tinggi menyebabkan permen terlalu lembut dan bagian luar meleleh, dan pada kondisi temperatur rendah menyebabkan bagian luar keras. Untuk itu perlu dirancang proses pembuatan yang memperhatikan kelembaban proses, sehingga permen yang dihasilkan sesuai dengan keinginan konsumen dan robust terhadap perubahan temperatur lingkungan.

Robust Desain ini telah menambahkan dimensi baru pada desain eksperimen klasik antara lain bagaimana mereduksi secara ekonomis variasi produk dalam lingkungan konsumen dan bagaimana menjamin bahwa keputusan untuk menerapkan kondisi optimum dalam eksperimen akan berhasil dalam manufaktur dan masyarakat.

\section{Variasi Yang Disebabkan Oleh Faktor} Tidak Terkontrol

Variasi adalah perbedaan yang terjadi dari suatu karakteristik kualitas antara satu produk dengan produk yang lain. Jika variasi yang terjadi sangat kecil, produk tersebut dianggap identik. Faktor yang menyebabkan variasi tersebut adalah faktor yang tidak terkontrol (noise factors) misalnya temperatur ruangan, kelembaban udara dan kualitas material. Faktor tidak terkontrol dapat dibagi menjadi tiga bagian yaitu

(Bellavendram,1995)

1. Faktor tidak terkontrol eksternal

2. Faktor tidak terkontrol internal

3. Faktor tidak terkontrol antar unit produk

\section{On-Line Quality Control}

On-line quality control merupakan pengendalian kualitas yang reaktif pada proses produksi yang sedang berjalan. Ada tiga bentuk On-line quality control yaitu: (Bellavendram,1995)

1. Proses diagnosis dan penyesuaian

2. Prediksi dan koreksi

3. Pengukuran dan aksi

\section{Off-Line quality Control}

Off-line quality control adalah pengendalian kualitas yang bersifat preventif. Off-line quality control dapat dikatakan sebagai desain proses dan produk sebelum 
sampai pada produksi di shop floor. Offline quality control dilakukan pada saat awal dari daur hidup produk (life cycle product), yaitu perbaikan pada awal untuk menghasilkan produk dengan kualitas tinggi. Produk dengan kualitas yang baik berarti variasi fungsi produk yang kecil untuk segala kondisi dari faktor tidak terkontrol.

Taguchi membagi tiga bagian utama dalam Off-line quality control yaitu : (Ross, 1989)

1. System design, Merupakan tahap pertama dalam desain dan merupakan tahap konseptual pada pembuatan produk baru atau inovasi proses.

2. Parameter design, Parameter design bertujuan untuk mereduksi ongkos dan meningkatkan kualitas dengan metode desain eksperimen.

3. Tolerance design, Tolerance design adalah proses melakukan kontrol terhadap faktor-faktor yang mempunyai pengaruh pad target dengan cara meningkatkan kualitas komponen tetapi tanpa menaikkan ongkos.

\section{Prinsip robustness dalam Desain}

Faktor tidak terkontrol tidak dapat dihilangkan karena faktor-faktor tersebut sudah ada dalam sistem. Selama produsen tidak dapat menangani faktor yang tidak terkontrol dengan baik, maka karakteristik kualitas seringkali tidak dapat mencapai target. Dengan demikian spesifikasi produk yang diharapkan tidak akan tercapai atau dengan kata lain akan terjadi kerugian (loss). Prinsip dasar dari kekokohan (robustness) adalah usaha untuk mereduksi kerugian dengan memperhatikan hubungan fungsional antara faktor terkontrol dan faktor tidak terkontrol, sehingga karakteristik kualitas tidak sensitif terhadap faktor tidak terkontrol. Untuk mereduksi kerugian ini dapat dilakukan secara tidak langsung dengan mereduksi variansi. Ada empat cara yang digunakan untuk mereduksi variansi yaitu mengeluarkan produk yang cacat, mencari dan menghilangkan penyebab ketidakcocokan, memperkecil toleransi dan menerapkan metode robust design.

\section{Klasifikasi karakteristik Kualitas}

Karakteristik kualitas adalah sesuatu yang menjadi obyek dan perhatian dari suatu produk atau proses. Karakteristik kualitas ini juga disebut karakteristik fungsi atau variabel respon. Misalnya antara lain : daya mesin, kekuatan hasil pengelasan, dimensi, dan penyusutan. Karakteristik kualitas dapat diklasifikasikan menurut nilai target yaitu : (Bellavendram,1995)

\section{Nominal is the best}

2. Smaller is better

3. larger is better

4. Signed-target

\section{Classified atribute}

\section{Klasifikasi faktor}

Faktor yang dapat mempengaruhi karakteristik kualitas (variabel respon) dari suatu produk ditunjukkan oleh gambar 2.2 berikut (Bellavendram,1995) 


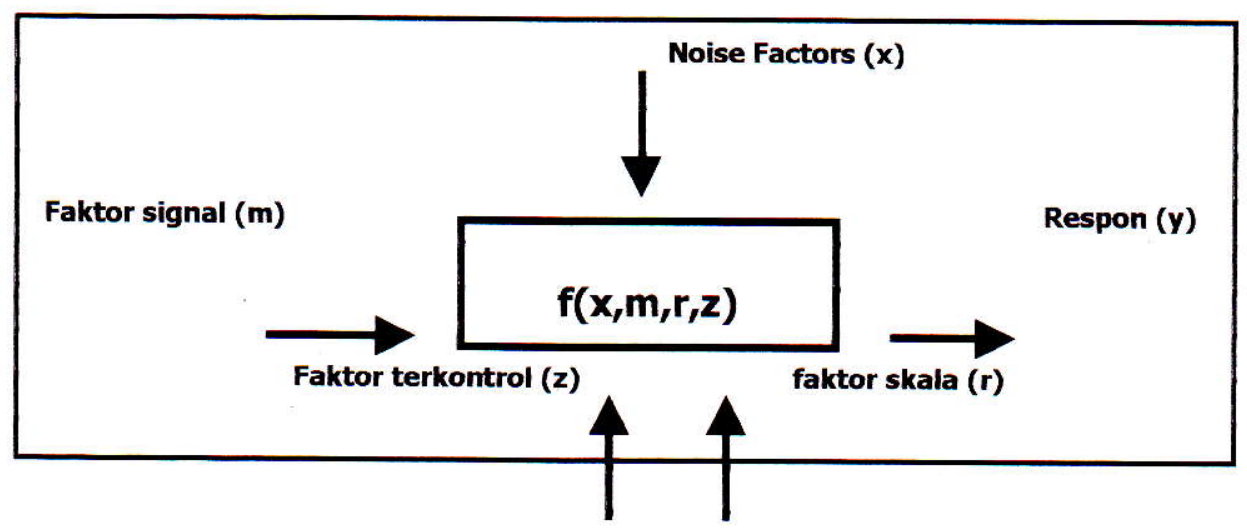

Gambar 2. Faktor yang mempengaruhi karakteristik kualitas

Dari gambar diatas dapat dijelaskan sebagai berikut :

1. faktor terkontrol adalah parameterparameter yang nilainya dapat dikontrol oleh ahli rekayasa desain.. Contoh : tipe material, aliran gas.

2. Faktor tidak terkontrol (noise factors) adalah parameter yang menjadi penyebab terjadinya variansi (deviation) karakteristik kualitas dari target..

3. Faktor signal adalah parameterparameter yang berupa signal.

4. Faktor skala (adjustment factors) adalah faktor yang berupa skala. Misalnya rasio gear pada setir mobil.

Dalam hal karakteristik kualitas yang bersifat dinamis (dynamic characteristic), seperti : kecepatan mobil (speed and direction), Taguchi (1990) mengklasifikan faktor terdiri atas 4 faktor yaitu :
a. Signal factor
b. Error factors
c. Signal factor
d. Error factors

\section{Eksperimen Dengan metode Taguchi}

Desain eksperimen dengan metode Taguchi termasuk dalam kelompok fractional factorial experiment. Taguchi menyusun orthogonal array untuk tata letak eksperimennya. Keuntungan dari orthogonal array (OA) adalah kemampuan untuk mengevaluasi beberapa faktor dengan jumlah test yang minimum. Taguchi hanya menyediakan dua macam orthogonal array dasar, yaitu orthogonal array dengan faktorfaktornya mempunyai dua level, dan orthogonal array dengan faktor-faktornya mempunyai 3 level. Jika orthogonal array yang siap pakai tidak tersedia maka perlu dilakukan modifikasi. Contoh orthogonal array adalah $\mathrm{L}_{8}\left(2^{7}\right)$ yang mempunyai arti 8 menyatakan baris yaitu banyaknya observasi, 2 menyatakan level dan 7 menyatakan kolom yaitu banyaknya faktor dan interaksi faktor.

Orthogonal Array Taguchi lebih baik dari fractional factorial experiment, dengan alasan sebagai berikut:

- Efisiensi dari fractional factorial experiment semakin berkurang jika semakin banyak faktor yang terlibat. 
口 Orthogonal Array Taguchi memberikan hasil yang serupa dan konsisten walaupun eksperimen dilakukan oleh orang yang berbeda.

- Tabel Orthogonal Array dapat digunakan untuk menentukan kontribusi dari setiap faktor yang berpengaruh terhadap kualitas.

\Orthogonal Array Taguchi lebih mudah dipahami walaupun terdapat banyak faktor yang terlibat.

Hasil yang diperoleh dari Orthogonal Array kemudian dianalisis untuk mencapai tujuan berikut:

- Mengestimasi kontribusi dari faktor yang berpengaruh terhadap kualitas.

a Memperoleh kondisi proses atau produk yang terbaik (optimum).

- Memperkirakan respon dari parameter desain produk pada kondisi optimum.

\section{Signal to Noise Ratio}

Dalam suatu eksperimen perlu dilakukan eliminasi faktor-faktor dan interaksinya yang kurang signifikan. Taguchi mengusulkan pooling up untuk mengakumulasikan beberapa variansi ke dalam error. Signal to noise ratio $(S / N$ ratio) digunakan untuk memilih faktorfaktor yang memiliki kontribusi pada pengurangan variansi suatu respon.

Rasio "Signal to noise $\left(\mathrm{S}_{\mathrm{n}}\right)$ adalah kontribusi original dari Taguchi pada rancangan eksperimen yang penting tetapi juga sekaligus kontroversial, karena sampai saat ini masih menjadi perdebatan. Taguchi mendefinisikan SN dengan rasio sebagai berikut :

$$
\begin{aligned}
\mathrm{SN}=\frac{(\text { Rata }- \text { rata })^{2}}{\text { Variance }}= & \frac{\mu^{2}}{\sigma^{2}} \ldots . .(2.1) \\
\text { Taguchi } & \text { menciptakan "new }
\end{aligned}
$$

performance measure" untuk kriteria pemilihan rancangan yang robust (kriteria uji hipotesa). Bandingkan dengan analisis variansi yang menggunakan ratio $F$ untuk kriteria uji hipotesa.

Secara umum, karakteristik response dapat dikelompokkan ke dalam :

\section{Nominal is the best :}

Untuk karakteristik kualitas dimana $\mathrm{y}_{\mathrm{I}}$, $(\mathrm{I}=1,2,3, \ldots, \mathrm{n})$, maka

$\mathrm{E}\left[\mathrm{y}_{\mathrm{I}}\right]=\mu$ dan $\mathrm{V}\left[\mathrm{y}_{\mathrm{I}}\right]=\sigma^{2}$. Nilai estimasi dari $\eta$ diperoleh dari prosedur berikut. Misalkan jumlah kuadrat $: \mathrm{S}_{\mathrm{T}}=\sum_{i=1}^{n} y_{i}^{2} \quad \mathrm{~S}_{\mathrm{m}}$ $=\frac{1}{n}\left(\sum_{i=1}^{n} y_{t}\right)^{2}$ dan $\mathrm{S}_{\mathrm{e}}=\mathrm{S}_{\mathrm{T}}-\mathrm{S}_{\mathrm{m}}=\sum_{i=1}^{n}\left(y_{i}-\bar{y}\right)^{2}$

Dengan $\bar{y}=\sum_{i=1}^{n} y_{i}$, Sehingga diperoleh : $\mathrm{E}\left[\mathrm{S}_{\mathrm{e}}\right]=(\mathrm{n}-1) \sigma^{2}$, dan $\mathrm{E}\left[\mathrm{S}_{\mathrm{m}}\right]=\mathrm{E}\left[\mathrm{S}_{\mathrm{T}}-\mathrm{S}_{\mathrm{e}}\right]=$ $\left.\mathrm{n}\left(\mu^{2}+\sigma^{2}\right)-(\mathrm{n}-1)\right) \sigma^{2}=n \mu^{2}+\sigma^{2}$,

Sedangkan square of mean $\mu^{2}$ dan variance $\sigma^{2}$ didefinisikan dengan

$$
\begin{aligned}
E\left[\frac{S_{e}}{n-1}\right]= & \sigma^{2} \text { dan } \\
& E\left[\frac{S_{m}}{n}-\frac{S_{e}}{n(n-1)}\right]=\mu^{2} \ldots . .
\end{aligned}
$$

Estimator yang unbiased pada square of mean $\mu^{2}$ dan variane $\sigma^{2}$ dapat diperoleh dari kedua persamaan.

Sehingga estimasi ratio $\mathrm{SN}$ adalah $\hat{\eta}=\frac{\left(S_{m}-S_{e} /(n-1)\right) / n}{S_{e} /(n-1)} \ldots$ 
dengan mencari nilai logaritmanya, diperoleh nilai decibel dari Signal to noise ratio sebagai :

$$
S N_{T}=10 \log \frac{\left(S_{m}-S_{e} /(n-1)\right) / n}{S_{e} /(n-1)} \cdots
$$

\section{The Smaller the better characteristic}

Untuk karakteristik kualitas dimana $\mathrm{y}_{\mathrm{l}}$, $(\mathrm{I}=1,2,3, \ldots, \mathrm{n})$, maka

Signal to noise ratio didefinisikan dengan

$\eta=\frac{1}{n} \sum_{i=1}^{n} y_{i}{ }^{2}$

nilai decibelnya adalah

$$
\mathrm{SN}_{\mathrm{s}}=10 \log \frac{1}{n} \sum_{i=1}^{n} y_{i}^{2}
$$

\section{Karena}

$\mathrm{E}\left[\mathrm{y}_{\mathrm{I}}\right]=\mu$ dan $\mathrm{V}\left[\mathrm{y}_{\mathrm{I}}\right]=\sigma^{2}$.

Nilai estimasinya menjadi :

$E\left[\frac{1}{n} \sum_{i=1}^{n} y_{i}{ }^{2}\right]=\mu^{2}+\sigma$

\section{The larger the better characteristic}

Untuk karakteristik kualitas dimana $\mathrm{y}_{\mathrm{I}}$, $(\mathrm{I}=1,2,3, \ldots, \mathrm{n})$, maka

Signal to noise ratio didefinisikan dengan

$$
\eta=\frac{1}{n} \sum_{i=1}^{n}\left(1 / y_{i}\right)^{2}
$$

Nilai decibelnya adalah

$$
\mathrm{SN}_{\mathrm{L}}=-10 \log \frac{1}{n} \sum_{i=1}^{n}\left(1 / y_{i}\right)^{2}
$$

Misalkan

$$
\begin{aligned}
& \frac{1}{n} \sum_{i=1}^{n}\left(1 / y_{i}\right)^{2}={ }^{\dagger} \sum^{n}(y-y+y)^{-2} \\
& \frac{1}{\bar{y}^{2}} \sum_{i=1}^{n}\left(1+\left(y_{i}-\bar{y}\right) / \bar{y}\right)^{-2}
\end{aligned}
$$

Dengan menggunakan ekspansi Taylor menghasilkan $\frac{1}{n} \sum_{i=1}^{n}\left(1 / y_{i}\right)^{2}=$

$\frac{1}{n \bar{y}^{2}} \sum_{i=1}^{n}\left[\left(1-2\left(\frac{y_{t}-\bar{y}}{\bar{y}}\right)+3\left(\frac{y_{i}-\bar{y}}{\bar{y}}\right)^{2}-4\left(\frac{y_{i}-\bar{y}}{\bar{y}}\right)^{3}+\ldots\right]\right.$

Jadi nilai estimasinya sebesar:

$\mathrm{E}\left[\frac{1}{n} \sum_{i=1}^{n}\left(1 / y_{i}\right)^{2}\right]=\frac{1}{\mu^{2}}\left(1+3 \frac{\sigma^{2}}{\mu^{2}}\right) \cdots \cdots$

Pemilihan Setting

Faktor-Faktor

\section{Terkontrol Yang Berpengaruh}

Menurut Lunani (1997) dan Bagchi(1993), ada dua tahap yang dilakukan untuk menentukan optimal level yaitu :

1. Faktor terkontrol yang penting pada reduksi variability ditentukan dan setting faktor yang sesuai dipilih, dengan kata lain memaksimalkan nilai rasio signal to noise ratio tanpa memperhatikan nilai rata-rata, sebab rasio signal to noise berkaitan dengan faktor yang tidak terkontrol (noise factors).

2. Faktor terkontrol yang memberi pengaruh penting pada sensitivitas pengukuran ratarata diidentifikasi dan level yang sesuai kemudian dipilih.

\section{PERKEMBANGAN ROBUST DESIGN}

Perkembangan dari penelitian mengenai robust design dapat dilihat pada Gambar 4. Penelitian mengenai Response Surface Methodology yang berkaitan dengan robust design merupakan perkembangan yang pertama kali muncul. Kemudian Nelder dan Lee (1991) mengajukan model generalized linear untuk memperbaiki kekurangan pada metode Taguchi. Beberapa tahun kemudian, Lunani et al. (1997) mengajukan metode grafik yang juga dikembangkan untuk memperbaiki kekurangan pada metode Taguchi. 


\section{Response Surface Methodology}

Beberapa penelitian menunjukkan bahwa Response Surface Methodology dapat digunakan untuk melakukan analisis yang tidak dapat dilakukan dengan metode Taguchi. Penelitian tersebut antara lain adalah penelitian Lucas (1989), Vining dan Myers (1990), Myers et al. (1992), dan Lucas (1994). Analisis Respon Surface melibatkan inner array dan outer array dimana efek dari outer array juga disertakan dalam analisis. Penelitian mengenai Response Surface Methodology kemudian dikembangkan lagi dalam beberapa penelitian berikutnya, antara lain oleh Ames et al. (1997), Joshi et al. (1998), dan Castillo et al. (1999).

Penelitian Ames et al. (1997) merupakan pengembangan dari Response Surface Methodology dengan permasalahan dimana terdapat respon lebih dari satu. Penelitian Joshi et al. (1998) merupakan pengembangan dari Response Surface Methodology dengan menggunakan Gradient Deflection untuk meningkatkan performansi dari Response Surface Methodology. Penelitian Castillo et al. (1999) merupakan pengembangan penelitian mengenai Dual Response Surface. Algoritma yang diajukan pada penelitian Castillo et al. (1999) merupakan algoritma heuristik yang efektif dalam memperoleh solusi optimal (atau mendekati optimal) untuk permasalahan dimana terdapat dua respon.

Dalam suatu diskusi ilmiah Lin dalam Myers (1999) menyatakan tentang prosedur atau flow chart dalam Response Surface Methodology yaitu :

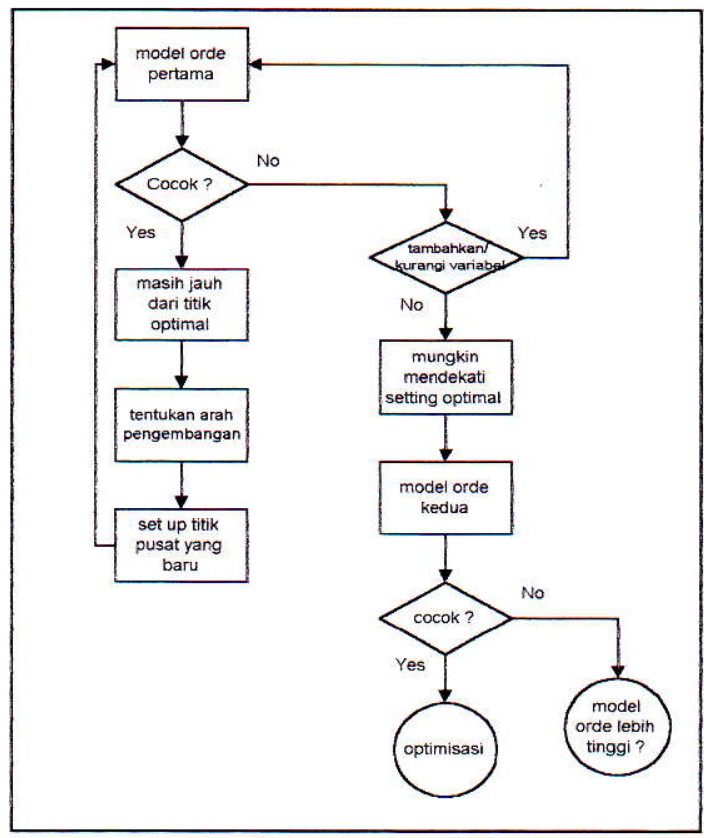

Gambar 3

Flowchart Response Surface Methodology

Dari gambaran flowchart diatas, terlihat bahwa Response Surface Methodology, masih sangat mungkin untuk dikembangkan untuk dapat memperoleh hasil yang optimal menuju Robust Design. Bahkan perkembangan yang paling terakhir menunjukkan bahwa metode Computer Generated Design dapat digunakan dalam Response Surface Methodology ini. (Myers, 1999).

\section{Generalized Linear Model}

Penelitian Nelder et al. (1991) membahas tentang Generalized Linear Model (GLM) khususnya model Gabungan Mean dan Dispersi yang merupakan pengembangan model linier klasik yang dibagi dalam 2 cara. Pertama, memungkinkan error muncul dari kelompok distribusi selain distribusi normal yaitu distribusi Poisson, binomial, 
multinomial, gamma, negatif binomial, dan invers distribusi Gauss. Kedua, GLM membagi membagi skala aditif pada efek variabel yang dapat dijelaskan dari spesifikasi struktur error. Sifat yang penting dari GLM adalah bentuk variansi $\operatorname{var}(\mathrm{y})=\phi \mathrm{V}(\mu)$. Hal ini menunukkan bahwa variansi membagi ke dalam 2 bagian yaitu $\phi$ yang disebut parameter dispersi yang independen pada mean dan $V(\mu)$ sebagai fungsi varian yang menggambarkan varian berubah menurut mean.

Penelitian Engel et al. (1996) tentang Generalized Linear Model merupakan pengembangan dari penelitian Nelder dan Lee (1991) dengan menambahkan pendekatan response surface. Pada penelitian tersebut, variabel noise dianggap menghasilkan efek yang tetap. Selain faktor noise, juga terdapat residual error yang merupakan faktor noise yang tidak dimasukkan ke dalam eksperimen.

\section{Dispersion Effects}

Penelitian Steinberg et al. (1994) membahas tentang efek dispersi akibat adanya noise factors dalam eksperimen robust design. Eksperimen dilakukan untuk mengetahui hubungan antara variabilitas dengan setting parameter proses terkontrol, sehingga dapat ditentukan besar parameter yang meminimumkan variasi. Parameter yang mempengaruhi variasi tersebut dikatakan memiliki efek dispersi. Dalam penelitian tersebut juga ditunjukkan bahwa jika noise factors dilibatkan dalam eksperimen maka efek dari noise factors tersebut harus dimodelkan secara eksplisit dalam analisis. Analisis full array dapt digunakan untuk mengetahui kontribusi dari noise factors terhadap variabilitas proses. Efek dispersi dapat diidentifikasi berdasarkan interaksi antara controllable factors dengan noise factors. Interaksi tersebut dilakukan untuk mendapatkan setting dari controllable factors yang mengurangi variabilitas proses.

\section{Graphical Methods}

Penelitian Lunani et al. (1997) tentang Graphical Methods memperlihatkan keterbatasan dari analisis SNR Taguchi. Pada penelitian ini diperlihatkan kelemahan analisis SNR yang dapat mengidentifikasi efek-efek dispersi yang salah, dengan mengusulkan dua metoda grafik, yaitu: sensitivity-standard deviation (SS) plot dan gamma-plot. SS plot merupakan pengembangan dari meanvariance plot yang digunakan untuk situasi desain parameter statik. Kemudian interpretasi dari gamma-plot adalah sama dengan lamdaplot.

\section{PEMBAHASAN DAN PENELITIAN KE DEPAN}

Pada bagian ini akan dibahas mengenai kelebihan dan kekurangan dari rancangan eksperimen yang diajukan oleh Taguchi. Kelebihan dari metode Taguchi adalah sebagai berikut:

- Rancangan eksperimen Taguchi memisahkan antara faktor tidak terkontrol dan faktor terkontrol. 
- Rancangan eksperimen Taguchi lebih efisien untuk eksperimen yang melibatkan banyak faktor, karena jumlah eksperimen yang diperlukan lebih sedikit daripada fractional factorial experiment sehingga menghemat waktu dan biaya.

- Rancangan eksperimen Taguchi memperhatikan pengaruh terhadap rata-rata dan variansi suatu performansi, ini memungkinkan diperolehnya suatu rancangan proses yang akan menghasilkan produk yang lebih konsisten.

- Hasil yang diperoleh bukan hanya mengenai faktor-faktor yang berpengaruh tetapi juga mengenai level-level faktor yang optimal.

Adapun kekurangan dari rancangan eksperimen Taguchi adalah sebagai berikut:

- Jika pemilihan rancangan eksperimen tidak sesuai, maka beberapa rancangan akan mengorbankan interaksi antar faktor yang terlibat.

- Dapat terjadi pembauran antara pengaruh utama dengan pengaruh interaksi.

- Pendekatan optimasi kualitas hanya berorientasi satu tujuan. Pada kasus multi tujuan, pertimbangan non-teknis (misalnya pengalaman atau intuisi) sering digunakan sebagai kompromi.

Berdasarkan kekurangan dari metode Taguchi tersebut maka terdapat beberapa kemungkinan perbaikan dan pengembangan terhadap metode Taguchi dalam lingkup quality by design. Kemungkinan perbaikan dan pengembangan yang dapat dilakukan antara lain:

1. Penelitian mengenai metode alternatif untuk mencapai robust design, khususnya yang berkaitan dengan reduksi variabilitas dari noise factors. Metode yang digunakan oleh Taguchi untuk meminimumkan variasi adalah SNR. Beberapa kelemahan dari metode SNR antara lain adanya kesulitan dalam mendapatkan faktor yang sesuai untuk masing-masing tahap optimasi level.

2. Pada bagan perkembangan penelitian robust design (Gambar 4) dapat dilihat bahwa metode Generalized Linear Model masih memungkinkan untuk dikembangkan karena metode ini relatif baru.

3. Perlunya dilakukan kajian yang lebih mendalam mengenai cara yang dapat dilakukan untuk mengurangi atau meniadakan efek dari adanya noise factors dalam suatu eksperimen (efek dispersi).

4. Penggunaan quality loss function untuk mendapatkan robust design merupakan peluang penelitian yang dapat dilakukan. Dengan menggunakan konsep loss function, SNR tidak lagi diperlukan untuk meminimumkan variasi dari noise factors.

5. Memperbaiki metode yang diusulkan oleh Pledger tentang klasifikasi dari uncontrollable factors, dimana pada metode tersebut belum bisa dijelaskan secara detail tentang konsep dari unobservable uncontrollable dan observable uncontrollable factors. 
6. Masih memungkinkan untuk DAFTAR PUSTAKA mengembangkan Response Surface Methodology (RSM) untuk orde yang lebih tinggi dan menggunakan konsep Generalized Linear Model serta konsep dynamic characteristic untuk pengembangan RSM.

\section{KESIMPULAN}

Kesimpulan yang dapat diperoleh dalam penelitian ini adalah sebagai berikut:

1. Quality by design merupakan tahap yang sangat penting dalam perbaikan kualitas karena pada tahap ini merupakan off-line quality control yang dilakukan sebelum produk mulai diproses.

2. Robust design Taguchi mempunyai kelebihan dan kekurangan. Oleh karena itu sangat memungkinkan untuk diperbaiki dan dikembangkan.

3. Metode SNR masih diperdebatkan, terutama dalam hal reduksi terhadap variansi.

4. Response Surface Methodology merupakan salah satu perkembangan dalam perbaikan kualitas untuk memperoleh robust design.

5. Generalized Linear Model merupakan metode yang relatif baru dalam perbaikan kualitas.

6. Sekurang-kurangnya terdapat 6 bidang kajian mengenai perbaikan dan pengembangan metode Taguchi (robust design).

Ames, A.E., Mattucci, N., MacDonald, S., Szonyi, G., Hawkins, D.M., 1997, Quality Loss Functions for Optimization Across Multiple Response Surfaces, Journal of Quality Technology, Vol. 29, No. 3, 339-353, Bagchi, T.P., 1993, Taguchi Methods Explained: Practical Steps to Robust Design, Prentice-Hall of India Private Limited, New Delhi.

Belavendram, N., 1995, Quality by Design: Taguchi Techniques for Industrial Experimentation, Prentice Hall International.

Engel, J., Huele, A.F., 1996, A Generalized Linear Modelling Approach to Robust Design, Technometrics, Vol. 38, 365373 ,

Irianto, D., (1999). “Metoda Eksperimen Taguchi”. Draft, April, Program Magister Teknik dan Manajemen Industri, ITB, Bandung.

Khattree, R., 1996, Robust Parameter Design: A Response Surface Approach, Journal of Quality Technology, Vol. 28, No. 2, 187-198,

Lucas, J.M., 1989, Achieving a Robust Process Using Response Surface Methodology, Proceeding of the Sesquicentennial Invited Paper Sessions of The American Statistical Association, 579-593,

Taguchi, G., 1987, System of Experimental Design, vol.2., American Supplier Institute.Inc, New York 